Agro-Science Journal of Tropical Agriculture, Food, Environment and Extension Volume 12 Number 1 January 2013 pp $66-72$

TSSN IIIY-7455

\title{
EFFECT OF GRADED DIETARY LEVELS OF GARCINIA KOLA SEED MEAL ON PERFORMANCE, INTESTINAL MICROBIAL LOAD, HAEMATOLOGICAL AND SERUM BIOCHEMICAL PROFILE OF RABBITS.
}

\author{
A.C. Esiegwu, G. E. Enyenihi, O.O. Emenalom, I.C. Okoli and A.B.I. Udedibie*
}

Department of Animal Science and Technology, Federal University of Technology P.M.B.

1526, Owerri - Nigeria.

*Corresponding Author: e-mail: abiu_futo@yahoo.com

\begin{abstract}
Effect of dietary Garcinia kola seed meal (GKSM) (bitter kola) on the performance, microbial activities and blood constituents of rabbits were investigated. Four rabbit grower mash were prepared such that diet $T_{0}$ (control) contained no Garcinia kola seed meal while diets $T_{1}, T_{2}$ and $T_{3}$ contained 2.5\%, 5.0\% and 7.5\% Garcinia kola seed meal, respectively, partly replacing maize. Each diet was fed to a group of 9 grower rabbits for 56 days, in completely randomized design (CRD) experiment. Each group was further subdivided into three replicates of 3 rabbits each. Faecal samples were collected from four rabbits per treatment at the first and last weeks of the experiment and used to determine intestinal microbial load of the rabbits. At the end of the feeding trial, blood samples were randomly collected from four rabbits per treatment and used to determine heamatological and serum biochemical profile of the rabbits. Body weight gain, daily body weight gain and feed conversion ratio ( $g$ feed/g gain) of the groups on GKSM diets decreased significantly $(P<0.05)$ while the feed intake increased $(P<0.05)$. GKSM had no significant effects $(P<0.05)$ on the parasite, cysts of Isospora belli, but significantly eradicated Salmonella and Streptococcus species. Haematological indices (RBC, HB, PCV, MCV, MCHC, MCH, WBC and platelets) were not affected by the treatments $(P>0.05)$. There were no traces of eosinophils, basophils and monocytes. Biochemical indices (serum cholesterol, serum protein, serum albumin, serum globulin) were also not significantly affected $(P>0.05)$ by the treatments. The glucose levels of GKSM fed groups were significantly $(P<0.05)$ reduced. The electrolytes (potassium, sodium and chloride) as well as calcium and bicarbonate levels were not affected by the treatments $(P>0.05)$. Cost of production (A/Kg gain) was highly increased with increase in dietary GKSM.
\end{abstract}

Key words: Diets, Garcinia kola, grower rabbits, performance.

\section{INTRODUCTION}

There is no doubt that the costs of providing feed and drugs in livestock and poultry industry in Nigeria are steadily increasing. These costs affect the final consumers of the products. South-eastern agro-ecological zone of Nigeria is highly endowed with plants possessing nutritional and medicinal properties. It has therefore become necessary to investigate such plants for possibilities of incorporating their leaves or seeds in livestock and poultry feeds to serve as feed ingredients and/or prophylactic agents. Earlier studies at our station have shown that leaves of Alchornia cordifolio (Udedibie and Opara, 1998) and Azadirchta indica (Esonu et al., 2005; Obikaonu, 2009) could be of value in poultry diets.
Garcinia kola, Heckel, commonly called bitter kola is an indigenous medicinal tree belonging to the family, guttiferae. It is highly valued because of its medicinal properties (Hertog et al., 1993). The seeds are chewed as an aphrodisiac or used to cure cough, dysentery or chest cold in herbal medicine (Irvine, 1961). Phytochemical studies have shown that the seed constituents include biflavoids, xanthones and benzophenones and which have anti-microbial, anti-inflammatory, anti-bacterial and anti-viral properties (Akoachere et al., 2002). Esiegwu and Udedibie (2009) reported that broilers placed on diets containing Garcinia kola seed meal produced heavier body weight and superior feed conversion ratio at $2.5 \%$ dietary level. Adedeji et 
al. (2008) also reported that it improved egg production performance of laying hens. However, no information is available on its nutritional value for rabbits although Uko et al. (2001) reported that its water extract had depressive effect on feed intake of rats.

The study herein reported was therefore designed to determine the effects of graded levels of Garcinia kola seed meal on the performance, intestinal microbial load and blood constituents of grower rabbits.

\section{MATERIALS AND METHODS}

Source and processing of Garcinia kola seeds

The Garcinia kola seeds used in the study were bought from Omuma market in Oru East Local Government Area of Imo State, Nigeria. The seeds were cut into small pieces and sun-dried until they became crispy. They were then milled in a hammer mill with $2 \mathrm{~mm}$ sieve to produce Garcinia kola seed meal (GKSM). Samples of the meal were subjected to proximate and mineral analysis according to AOAC (1990).

\section{Experimental diets}

Four grower rabbit diets were compounded, incorporating Garcinia kola seed meal at $0 \%$, $2.5 \%, 5.0 \%$ and $7.5 \%$ inclusion levels, partly replacing maize. The diets were designated $\mathrm{T}_{0}$, $\mathrm{T}_{1}, \mathrm{~T}_{2}$ and $\mathrm{T}_{3}$, respectively, with $\mathrm{T}_{\mathrm{o}}$ serving as the control. The ingredient and nutrient compositions of the diets are shown in Table 1.

\section{Experimental rabbits and design}

Thirty-six eight weeks old grower rabbits of mixed breeds were randomly divided into four groups of nine rabbits each which were randomly assigned to one of the four experimental diets, using completely randomized design (CRD). Each group was further subdivided into three replicates of three (3) rabbits each. The rabbits were individually housed in $0.7 \mathrm{~m} \times 1.0 \mathrm{~m}$ hutches. Feed and water were supplied ad libitum in separate earthen troughs. The trial lasted for 8 weeks (56 days).

\section{Data collection and analysis}

The rabbits were weighed at the beginning of the experiment to obtain their initial body weights and then weekly thereafter. Daily feed intake was determined by subtracting the weight of leftover feed from the weight of the feed fed the previous day. Feed conversion ratio was determined by dividing average daily feed intake by average daily body weight gain. Cost of production was determined by multiplying cost of feed $(\AA / \mathrm{kg})$ by feed conversion ratio $(\mathrm{kg}$ feed/kg gain).

\section{Microbial studies}

Faecal samples were collected from 4 rabbits per treatment at the first and last weeks of the experiment and analysed for presence of parasites. The faecal samples were cultured according to the method of Monica (2000) for presence of Salmonella specie, Escherichia coli, Streptococcus specie and Staphylococcus aureus.

\section{Haematological and Serum Biochemical Analysis}

Blood samples were collected at the end of the 56-day feeding trial from 4 rabbits per treatment through neck slitting and used for determination of haematological/serum biochemical indices. Blood was collected from each rabbit and about $2 \mathrm{ml}$ of each sample was put into well labeled sterilized bijon bottles containing EDTA as anticoagulant, while another $6 \mathrm{ml}$ was put in bottles without EDTA to produce serum for determination of serum biochemical indices. Blood samples were analysed within three hours of collection for haemoglobin $(\mathrm{Hb})$ level, white blood cell (WBC), red blood cell (RBC), packed cell volume (PCV), platelets, and differential white cell counts (percentage neutrophils, basophils, eosinophils, lymphocytes and monocytes) using standard methods (Monica, 1984). Mean corpuscular volume (MCV), mean corpuscular haemoglobin $(\mathrm{MCH})$ and mean corpuscular haemoglobin concentration (MCHC) were calculated. Serum biochemical indices analysed included blood glucose, serum total protein, globulin, albumin, serum cholesterol, sodium, potassium, calcium, chloride and bicarbonate.

\section{RESULTS AND DISCUSSION}

Proximate and mineral composition.

The proximate and mineral compositions of Garcinia kola seeds used for the experiment are shown in Table 2.

With the exception of crude fiber, which was $20.51 \%$, other values (crude protein, ether extract and ash) were in agreement with the values earlier reported by Ibekwe (2007). The values for $\mathrm{Mn}, \mathrm{Mg}, \mathrm{Ca}$ and $\mathrm{K}$ were close to the values of $2.01 \mathrm{mg} / 100 \mathrm{~g}$ for $\mathrm{Mn}, 0.42 \mathrm{mg} / 100 \mathrm{~g}$ for $\mathrm{Mg}, 0.80 \mathrm{mg} / 100 \mathrm{~g}$ for $\mathrm{Ca}$ and $2.50 \mathrm{mg} / 100 \mathrm{~g}$ for $\mathrm{K}$ respectively, reported by Okwu (2005). The value for $\mathrm{Zn}(0.03 \mathrm{mg} / \mathrm{g})$ tended to agree with the values of $2.30 \mathrm{mg} / 100 \mathrm{~g}$ and $2.30 \mathrm{mg} / \mathrm{kg}$ reported by Okwu (2005) and Odebunmi et al. (2009), respectively. It is therefore more of a source of carbohydrates 
Table 1: Ingredient composition of the experimental diets.

\begin{tabular}{|c|c|c|c|c|c|}
\hline \multirow[b]{2}{*}{ Ingredients (\%) } & \multicolumn{4}{|c|}{ Dietary levels of GKSM } & \multirow[b]{3}{*}{39.50} \\
\hline & $\mathrm{T}_{0}(0.00 \%)$ & $\mathrm{T}_{1}(2.5 \%)$ & $\mathrm{T}_{2}(5.0 \%)$ & $\mathrm{T}_{3}(7.5 \%)$ & \\
\hline Maize & 47.00 & & 44.50 & 42.00 & \\
\hline GKSM & 0.00 & & 2.50 & 5.00 & 7.50 \\
\hline Soya bean meal & 9.00 & & 9.00 & 9.00 & 9.00 \\
\hline Fishmeal & 2.00 & & 2.00 & 2.00 & 2.00 \\
\hline Blood meal & 1.00 & & 1.00 & 1.50 & 1.50 \\
\hline Wheat offal & 26.00 & & 26.00 & 25.50 & 25.50 \\
\hline Palm kernel cake & 11.00 & & 11.00 & 11.00 & 11.00 \\
\hline Bone meal & 3.00 & & 3.00 & 3.00 & 3.00 \\
\hline Common salt & 0.25 & & 0.25 & 0.25 & 0.25 \\
\hline Vit./Tm premix* & 0.25 & & 0.25 & 0.25 & 0.25 \\
\hline L-lysine & 0.25 & & 0.25 & 0.25 & 0.25 \\
\hline L-methionine & 0.25 & & 0.25 & 0.25 & 0.25 \\
\hline \multicolumn{6}{|c|}{ Calculated Chemical Composition ( $\%$ of DM) } \\
\hline $\mathrm{Cp}$ & 16.31 & & 16.15 & 15.99 & 15.84 \\
\hline $\mathrm{CF}$ & 5.71 & & 6.15 & 6.60 & 7.05 \\
\hline $\mathrm{EE}$ & 4.47 & & 4.61 & 4.74 & 4.88 \\
\hline Ash & 3.72 & & 3.72 & 3.71 & 3.70 \\
\hline NFE & 69.79 & & 69.37 & 68.96 & 68.53 \\
\hline $\mathrm{Ca}$ & 1.24 & & 1.24 & 1.24 & 1.24 \\
\hline $\mathrm{P}$ & 1.12 & & 1.11 & 1.10 & 1.09 \\
\hline Lysine & 1.03 & & 1.03 & 1.02 & 1.01 \\
\hline Methionine, & 0.55 & & 0.54 & 0.54 & 0.53 \\
\hline $\mathrm{ME}(\mathrm{mcal} / \mathrm{kg})$ & 2.54 & & 2.53 & 2.51 & 2.50 \\
\hline \multicolumn{6}{|c|}{$\begin{array}{l}\text { Provided the following per kilogram of diet: Vit. A, } 10,000 \mathrm{iu} \text {; Vit. } \mathrm{D}_{3}, 2000 \mathrm{iu} \text {; Vit. E, } 5 \text { iu; Vit. K, } 2 \mathrm{mg} \text {; riboflavin, } 4.20 \mathrm{mg} \text {; Vit. B } \\
0.01 \mathrm{mg} \text {; panthotenic acid, } 5 \mathrm{mg} \text {; nicotinic acid, } 20 \mathrm{mg} \text {; folic acid, } 0.5 \mathrm{mg} \text {; chloride, } 3 \mathrm{mg} ; \mathrm{Mg}, 56 \mathrm{mg} ; \mathrm{Fe}, 20 \mathrm{mg} \text {; Cu, } 10 \mathrm{mg} \text {; Zn, } 50 \mathrm{mg} \text {; } \\
\text { Co, } 125 \mathrm{mg} \text {. }\end{array}$} \\
\hline \multicolumn{6}{|c|}{ Table 2: Proximate and mineral composition of Garcinia kola seeds (DM basis) } \\
\hline \multicolumn{6}{|c|}{ Proximate composition (\% of DM) } \\
\hline Dry matter & & 92.70 & & & \\
\hline Crude protein & & 2.64 & & & \\
\hline Crude fibre & & 20.51 & & & \\
\hline Ether extract & & 9.47 & & & \\
\hline Ash & & 1.07 & & & \\
\hline Nitrogen free extract & & 57.54 & & & \\
\hline \multicolumn{6}{|c|}{ Macro elements $(\mathrm{mg} / \mathrm{g})$} \\
\hline Magnesium & & 0.28 & & & \\
\hline Calcium & & 0.25 & & & \\
\hline Potassium & & 1.61 & & & \\
\hline Phosphorus & & 0.057 & & & \\
\hline Sodium & & 0.282 & & & \\
\hline Chlorine & & 0.400 & & & \\
\hline Sulphur & & 0.073 & & & \\
\hline \multicolumn{6}{|l|}{ Micro elements (mg/g) } \\
\hline$\overline{\mathrm{Fe}}$ & & 0.21 & & & \\
\hline Zinc & & 0.03 & & & \\
\hline Cupper & & 0.52 & & & \\
\hline Manganese & & 0.12 & & & \\
\hline
\end{tabular}


Effect of Graded Dietary Levels of Garcinia Kola Seed Meal on Performance,

\section{Performance of the Experimental Rabbits}

Data on the performance of the experimental rabbits are presented in Table 3.

Body weight gain, daily body weight gain and feed conversion ratio of the groups on GKSM diets were significantly $(\mathrm{P}<0.05)$ reduced. These findings corroborate the report of Uko et al. (2001) that water extract from Garcinia kola caused poor feed utilization efficiency and weight gain of rats. The poor performance of the rabbits on GKSM diets could be attributed to the presence of anti-nutritional factors in Garcinia kola, especially tannin (Esiegwu and Udedibie, 2009). Condensed tannin from the browse plant Robin's Pseudoacacia has been reported to cause reduced growth and coprophagy in rabbits (Raharjo et al., 1990) and reduced protein digestibility in rats (Horigone et al., 1988). Lebas et al. (1997) reported that through coprophagy, rabbits obtain a significant amount of water soluble vitamins, up to $20 \%$ of its crude protein (CP) requirement, $30 \%$ of its energy requirements as volatile fatty acids (VFA) and $18 \%$ of its dry matter intake. Feed intake of the rabbits, however, was significantly $(\mathrm{P}<0.05)$ increased by Garcinia kola seed meal. This finding is in agreement with the report of Esiegwu and Udedibie (2009) on broilers fed graded levels of Garcinia kola seed meal but contradicts that of Uko et al. (2001) that rats fed water extract from Garcinia kola hard depressed appetite and water intake. Feed costs increased as dietary levels of Garcinia kola seed meal increased due to the high cost of the test material. This invariably resulted in very high cost of production of the rabbits as the dietary levels of the meal increased.

Table 3: Performance of grower rabbits fed graded levels of Garcinia kola seed meal

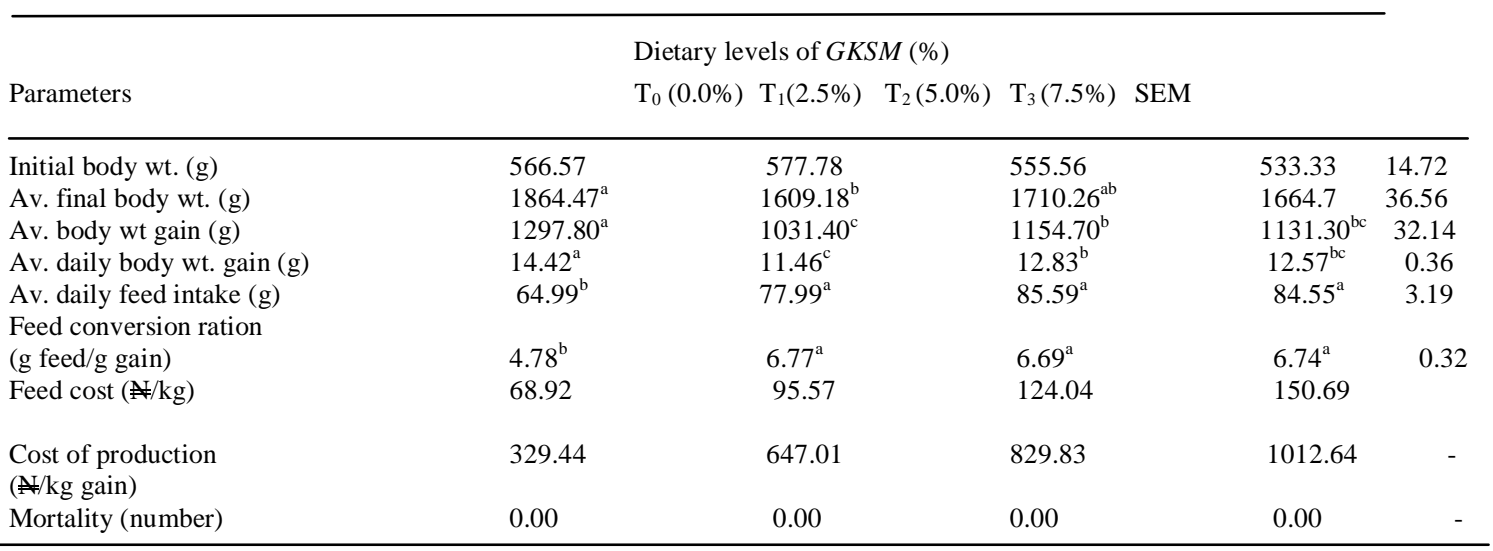

${ }^{\text {abc }}$ Means within the same row with different superscripts are significantly different $(\mathrm{P}<0.05)$.

Table 4: Parasitological observations on the rabbits fed Garcinia kola seed meal

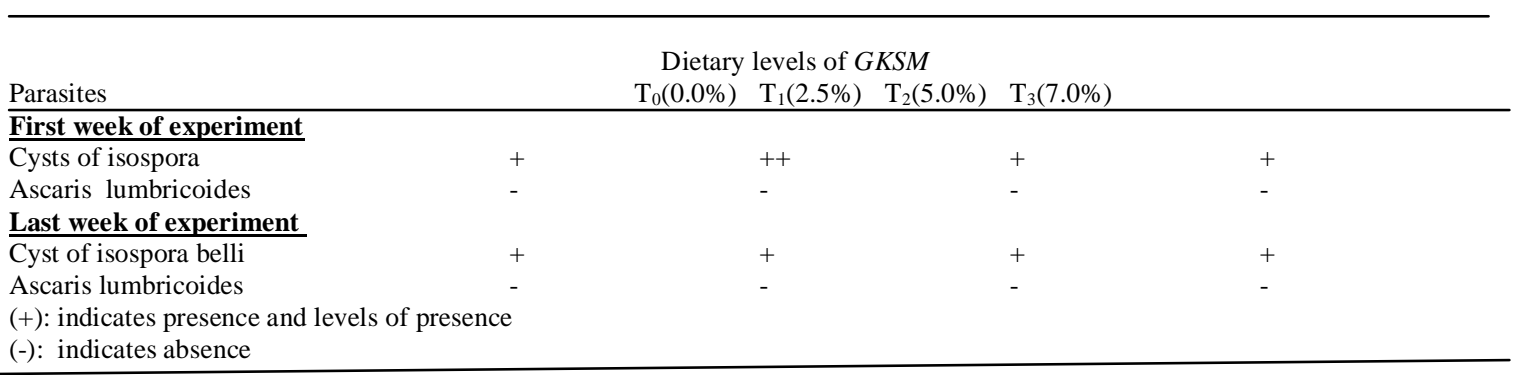


A.C. Esiegwu, G. E. Enyenihi, O.O. Emenalom, I.C. Okoli and A.B.I. Udedibie

Table 5: Bacterial observations on the rabbits fed graded levels of Garcinia kola seed meal

\begin{tabular}{|c|c|c|c|c|c|}
\hline Bacteria & $\mathrm{T}_{0}(0.0 \%)$ & $\mathrm{T}_{1}(2.5 \%)$ & $\mathrm{T}_{2}(5.0 \%)$ & $\mathrm{T}_{3}(7.5 \%)$ & \\
\hline \multicolumn{6}{|c|}{ First week of experiment } \\
\hline Salmonella spp & ++ & & ++ & + & - \\
\hline Staphylococcus aureus & + & & - & ++ & + \\
\hline Escherichia coli & + & & ++ & ++ & + \\
\hline Streptococcus spp & - & & - & + & - \\
\hline \multicolumn{6}{|c|}{ Last week of experiment } \\
\hline Salmonella spp & ++ & & - & - & - \\
\hline Staphylococcus aureus & + & & + & - & ++ \\
\hline Escherichia coli & + & & + & ++ & + \\
\hline Streptococcus spp & - & & - & - & - \\
\hline
\end{tabular}

$(+)$ : indicates presence and levels of presence

(-): indicates absence

Table 6: Haematological and Serum biochemical indices of grower rabbits fed graded levels of Garcinia kola seed meal

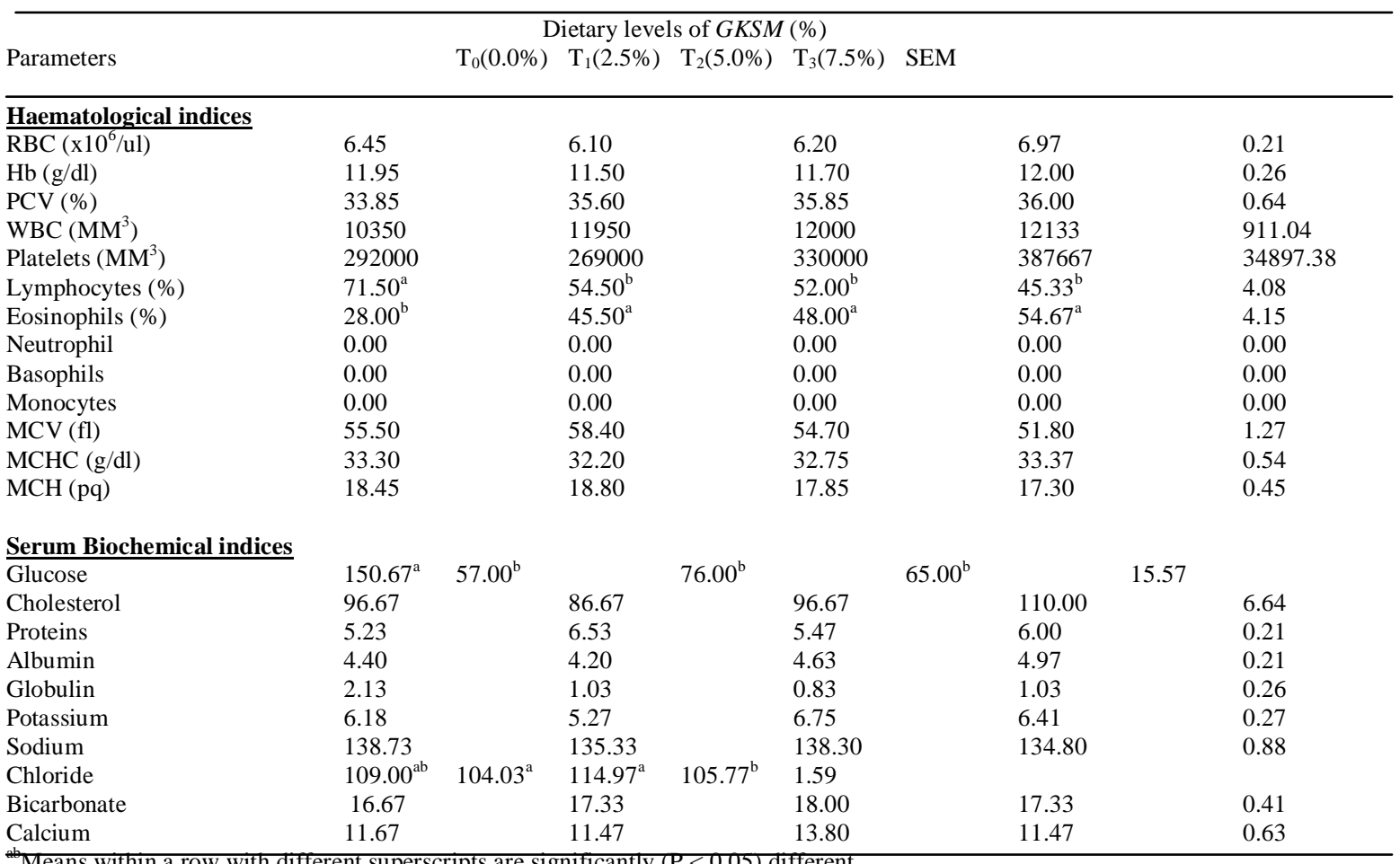

ent superscripts are significantly (P< 0.05) different.

\section{Microbial Observations}

Data from bacteriological and parasitological studies are presented in Tables 4 and 5. Clinical evaluation of the faecal samples revealed the presence of Isospora belli at the beginning and end of the experiment (Table 4), indicating that Garcinia kola has no effect on Isospora belli in rabbits. Bacteriological analysis of the faecal samples at the beginning and end of the experiment (Table 5) revealed that Garcinia kola may be bactericidal to Salmonella and Streptococcus species, supporting the report of Ebana et al. (1991) and Akoachere et al. (2002) that the seeds of Garcinia kola to some extent have anti-bacterial and anti-microbial properties.
Garcinia kola had no significant anti-bacterial effect ( $\mathrm{P}>0.05)$ on Staphylococcus aureus and Escherichia coli.

\section{Haematological and Serum Biochemical Indices}

Data on haematological and serum biochemical indices of the rabbits are presented in Table 6 . There were no significant differences $(\mathrm{P}>0.05)$ in most of the indices evaluated $(\mathrm{RBC}, \mathrm{Hb}$, $\mathrm{PCV}, \mathrm{WBC}, \mathrm{MCV}, \mathrm{MCHC}, \mathrm{MCH}$, platelets as well as the differential white cell counts, neutrophils, basophils and monocytes). However, GKSM significantly $(\mathrm{P}<0.05)$ reduced lymphocytes and enhanced eosinophils 
of the rabbits. The values of the indices were, however, within the ranges reported as normal for rabbits (MacNamee and Sheeley, 1952; Mitruka and Rawnsley, 1977; Kathy, 2003; Ahamefule et al., 2006). The findings are in agreement with the earlier reports of Uko et al. (2001) and Adedeji et al. (2005) on the effects of Garcinia kola seeds on blood profile of rats. With exception of glucose which was significantly $(\mathrm{P}<0.05)$ reduced by dietary Garcinia kola seed meal, serum biochemical indices were not affected by the treatments $(\mathrm{P}>$ $0.05)$. The values obtained were, however within the ranges reported as normal by CCAC (1980) for rabbits, an indication that Garcinia kola seed meal has no negative or deleterious effects on blood profile of rabbits

\section{CONCLUSION AND RECOMMENDATION}

The results of the study have shown that Garcinia kola seed meal has negative effect on growth performance of rabbits. Even though it can eliminate Salmonella species and has no deleterious effects on blood profile of rabbits, it cannot be recommended as feed ingredient or additive in view of the poor growth performance of the rabbits and high cost of production.

\section{REFERENCES}

Adedeji, O.S., Farinu, G.O., Ameen, S.A. and Oyewope, A.O. (2005). The effects of different dietary inclusion levels of bitter kola (Garcinia kola) on blood profiles of laboratory rats. Tropical Veterinarian, 23 (2): $56-60$.

Ahamefule, H., Eduok, G. O., Usman, A., Ahamefule, K. U., Obua, B. E. and Oguike, S. A. (2006). Blood biochemistry and haematology of rabbits fed sun-dried ensiled and fermented cassava peel-based diets. Journal of Nutrition, 5(3): 248 - 253.

Akoachere, J.F., Ndip, R.N., Chenwi, E.B., Ndip, L.M., Njock, T.E. and Anong, D.N. (2002). Antibacterial effect of Zingiber officinale and Garcinia kola on respiratory tract pathogens. East Afr. Med. J., 79 (11): 588 - 592.

AOAC. (1990). Association of Official Analytical Chemists, Official Methods of Analysis, $13^{\text {th }}$ Edition, Washington D.C., USA.

Canadian Council on Animal Care, CCAC (1980). Guide to the care and use of experimental animals. CCAC, 1: 82 90.

Ebana, R.U., Madunagu, B.E., Ekpe, E.D. and Otung, I.N. (1991). Microbiological exploitation of cardiac glycosides and alkaloids from Garcinia kola, Borreria ocymoides, Kola nitida and Citrus aurantifolia. J. Appli. Bacteriol., 71(5): $398-401$.

Esiegwu, A.C. and Udedibie, A.B.I. (2009). Growth performance of and antimicrobial activities in broilers fed supplementary bitter kola (Garcinia kola). Animal Production Research Advances, 5(1): 20 - 24.

Esonu, B. O., Emenalom, O.O., Udedibie, A.B.I., Anyanwu, G.A., Madu, U. and Inyang, A.O. (2005). Evaluation of neem (Azadirchta indica) leaf meal on performance, carcass characteristics and egg quality of laying hens. Intl. J. Agric. Rural Devt., (6): 208 - 212.

Hertog. M.G.I., Fejkeen, E.J.M., Hokman, C.H. and Katan, A. (1993). Dietary antioxidant flavonoids and risk of coronary heart disease, de zutphen elderly study. Lancet, 342: 2007 1011.

Horigone, T., Kumar, R. and Okamoto, k. (1988). Effects of condensed tannins prepared from the leaves of fodder plants on digestive enzymes in vitro and in the intestine of rats. British Journal of Nutrition, 60: $275-285$.

Ibekwe, H.A., Eteng, M.U. and Antigha, E. (2007). Proximate and phytochemical composition of Garcinia kola and Vernonia amygdalina. Proceedings of the $32^{\text {nd }}$ Annual Conf. of the Nig. Soc. for Anim. Prod., Calabar, March 18 21, 2007, pp. $255-258$.

Irvine, F. R. (1961). Woody Plants of Ghana with Special Reference to Their Uses. Oxford University press, London.

Kathy, S. (2003). Rabbit Health in the $21^{\text {st }}$ Century. A Guide to Bunny Parents. $2^{\text {nd }}$ edition. Pp. 131 - 140.

Lebas, F., Corring, T. and Courtot, D. (1997). Equipment enzymatique du pancrease exocrine chez le lapin, mise en place et evolution de la naissance au servage. Relation avec la composition du regime alimentaire. Animal Biochemistry and Biophysics, 11: 399 - 413.

MacNamee, J. K. and Sheely, R. W. (1952). The use of the small laboratory animal for repeated clinical pathological studies. Inc. Book, Anim. Vet. Med. Assoc. $89^{\text {th }}$ Inc. Session, 138.

Mitruka, B. M. and Rawnsley H. M. (1977). Clinical, Biochemical and Haematological Reference Values in Normal Experimental Animals. Masson Publishing USA Inc. NY, Pp. 21 - 84, 278, 106 - 112. 
Monica, C. (1984), Medical Laboratory Manual for Trop. Countries. Vol. 11, Microbiology ELBS ed.

Monica, C. (2000). District Laboratory Practice in Tropical Countries (part 2). Cambridge University Press.

Obikaonu, H.O. (2009). Production Performance of and Anticoccidial Effects in deep litter managed chickens fed neem leaf meal. Ph.D Thesis, Fed University of Technology, Owerri - Nigeria.

Odebunmi, E.O., Oluwaniyi, O.O., Awolola, G.V. and Adediji, O.D. (2009). Proximate and nutritional composition of kola nut (Cola nitida), bitter cola (Garcinia kola) and alligator pepper (Afromomum melegueta). African Journal of Biotechnology, 8(2): 308 310.
Okwu, D.E. (2005). Phytochemical, vitamin and mineral contents of two Nigerian medicinal plants. International Journal of Molecular Medicine and Advance Sciences, 1(4): 375 - 381.

Raharjo, Y.C, Cheeke, P.R. and Patton, N.M. (1990). Effect of cecotrophy on nutrient digestibility of alfalfa and blank locust leaves. Journal of Applied Rabbit Research, 13: $56-61$.

Udedibie, A.B.I. and Opara, C.C. (1998). Response of growing broilers and laying hens to dietary inclusion of leaf meal from Alchornia cordifolia. Anim. Fd. Sci. Tech., 71: $157-164$.

Uko, O.J., Usman, A. and Ataja, A. M. (2001). Some biological activities of Garcinia kola in growing rats. Vet. Arhiv., 71: $287-297$. 